Original Research Paper

\title{
Karateristik/Spesifikasi Alat Laboratorium Fisika dan Cara Penggunaanya pada Mahasiswa S1 Jurusan Pendidikan MIPA FKIP Universitas Mataram
}

\author{
Fidiani Fidiantara $^{1}$, Husnul Fuadi ${ }^{12^{*}}$, Wahyu Bintang Ilahi ${ }^{1}$, Jamaluddin $^{1}$ \\ ${ }^{1}$ Program Studi Magister Pendidikan IPA, Pascasarjana Universitas Mataram, Indonesia \\ ${ }^{2}$ Teknisi Laboratorium Pendidikan Fisika FKIP Universitas Mataram, Indonesia
}

DOI: https://doi.org/10.29303/jpmpi.v4i2.666

Sitasi: Fidiantara, F., Fuadi, H., \& Ilahi, W.B. (2021). Karateristik/Spesifikasi Alat Laboratorium Fisika dan Cara Penggunaanya pada Mahasiswa S1 Jurusan Pendidikan MIPA FKIP Universitas Mataram. Jurnal Pengabdian Magister Pendidikan IPA, 4(2)

\author{
Article History \\ Received: 03 Februari 2021 \\ Revised: 08 Maret 2021 \\ Accepted: 06 April 2021 \\ *Corresponding Author: \\ Husnul Fuadi, \\ Program Studi Magister \\ Pendidikan IPA, Pascasarjana \\ Universitas Mataram, Indonesia
}

Email: husnul.fuadi@unram.ac.id

\begin{abstract}
Keterampilan pada abad 21 menjadi fokus utama pendidikan saat ini, khususnya pada pendidikan IPA. Keterampilan ini menjadi kebutuhan dasar dari pembelajaran sains yang saat ini masih kurang tepat dibelajarkan di sekolah. Kegiatan ini bertujuan untuk memberikan pemahaman dan keterampilan terhadap karakteristik/spesifikasi alat - alat laboratorium fisika kepada mahasiswa jurusan PMIPA FKIP Universitas Mataram. Metode yang digunakan yaitu praktek langsung penggunaan alat - alat laboratorium seperti jangka sorong, micrometer sekrup, multimeter, neraca ohaus dan catu daya yang dipandu oleh teknisi laboratorium sebagai salah satu tim pengabdi. Kegiatan ini mampu memberikan peningkatan pemahaman dan keterampilan bagi para peserta terlihat dari hasil pretest dan posttest pada saat kegiatan. Pelatihan penggunaan alat - alat laboratorium penting dilakukan sebagai modal dasar bagi calon guru IPA di Sekolah.
\end{abstract}

Keywords: Abad 21, Alat Laboratorium, Guru IPA

\section{Pendahuluan}

Pandemi COVID-19 mengakibatkan
perubahan dalam berbagai aspek kehidupan,
khususnya dalam bidang pendidikan (Erni, et al.,
2020). Tercatat sejak pertengahan Bulan Maret
2020 sekolah/Perguruan Tinggi di Indonesia sudah
tidak lagi mengadakan proses pembelajaran secara
langsung (Setiawan, 2020). Berdasarkan arahan
Kementerian Pendidikan dan Kebudayaan
Pemerintah, telah melarang perguruan tinggi untuk
melaksanakan perkuliahan secara langsung
(konvensional) dan memerintahkan untuk
melaksanakan perkuliahan atau pembelajaran
secara daring/tidak langsung (Surat Edaran
Kemendikbud Dikti No. 1 Tahun 2020). Dengan
adanya intruksi tersebut semua lembaga pendidikan
di Indonesia harus menyiapkan layanan pendidikan
yang sesuai dengan situasi dan kondisi sekarang
(Ayuni, et al., 2020). Perkembangan Teknologi dan
Informasi (TI) di era 4.0 sangat berpengaruh terhadap sistem pembelajaran saai ini (Sofyana \& Abdul, 2019). Salah satunya adalah pembelajaran daring/tidak langsung, dimana pembelajaran daring menghubungkan peserta didik dengan sumber belajarnya (database, pakar/instruksi, perpustakaan) yang secara fisik terpisah atau bahkan berjauhan namun dapat saling berkomunikasi, berinteraksi atau berkolaborasi (secara langsung/synchronous dan secara tidak langsung/asynchronous) (Sadikin \& Afreni 2020). Hal ini sangat mempengaruhi pengetahuan dan keterampilan peserta didik/mahasiswa terhadapat suatu pembelajaran. Kegiatan pembelajaran pada hakekatnya adalah suatu proses interaksi atau hubungan timbal balik antara guru/dosen dan peserta didik/mahasiswa dalam satuan pembelajaran (Handayani, 2020). Namun, situasi saat ini mengakibatkan sulitnya transformasi ilmu dari guru/dosen kepada peserta didik/mahasiswa, khususnya dalam pembelajaran 
Ilmu Pengetahuan Alam (IPA) yang menekankan adanya Praktikum di Laboratorium. Jika dibandingkan dengan tahun sebelumnya, mahasiswa mendapat praktek langsung cara penggunaan alat di Laboratorium sehingga pengetahuan dan keterampilan mahasiswa semakin bertambah, sedangkan untuk tahun ini mahasiswa hanya sekedar mengetahui alatnya tanpa tahu bagaimana cara mengoperasikan alatnya secara langsung sehingga bisa terjadi miskonsepsi. Pembelajaran yang tidak kontekstual ini menjadi salah satu penyebab rendahnya literasi sains peserta didik, sebagaimana yang diungkapkan oleh Fuadi, $\mathrm{H}$ et al., 2020 bahwa faktor-faktor yang menyebabkan rendahnya literasi sains peserta didik diantaranya adalah pemilihan buku ajar, miskonsepsi, pembelajaran yang tidak kontekstual, dan kemampuan membaca peserta didik.

Pembelajaran daring memiliki dampak yang sangat signifikan terhadap minat belajar dan keterampilan peserat didik, karena sebelumnya belum ada budaya belajar jarak jauh yang diterapkan di sekolah-sekolah (Purwanto, et al., 2020). Jika dilihat secara umum maka bisa dikatakan bahwa mahasiswa S1 yang menempuh Program Studi MIPA saat ini memiliki keterampilan yang lebih rendah dalam mengoperasikan alat-alat laboratorium, dari pada mahasiswa S1 Program Studi MIPA sebelum pandemi. Keterampilan dalam mengoperasikan alat-alat Laboratorim seharusnya didapatkan oleh mahasiswa saat melakukan Praktikum di Laboratorium, seperti mampu mengoperasikan catu daya sebagai sumber listrik dan Mikrometer Sekrup untuk mengukur ketebelan benda yang sangat tipis. Keterampilan ini sangat dibutuhkan oleh mahasiswa, terutama mahasiswa FKIP yang akan menjadi calon-calon Guru di sekolah. Oleh karena itu, untuk meningkatkan keterampilan mahasiswa dalam mengoperasikan alat-alat Laboratorium peneliti bermaksud untuk melakukan pengabdian masyarakat dengan Topik Karateristik/spesifikasi alat - alat Laboratorium Fisika dan cara penggunaanya pada Mahasiswa S1 Jurusan Pendidikan MIPA FKIP Universitas Mataram.
Pengabdian ini dilakukan pada bulan Februari 2021 di Laboratorium Pendidikan Fisika FKIP Universitas Mataram.

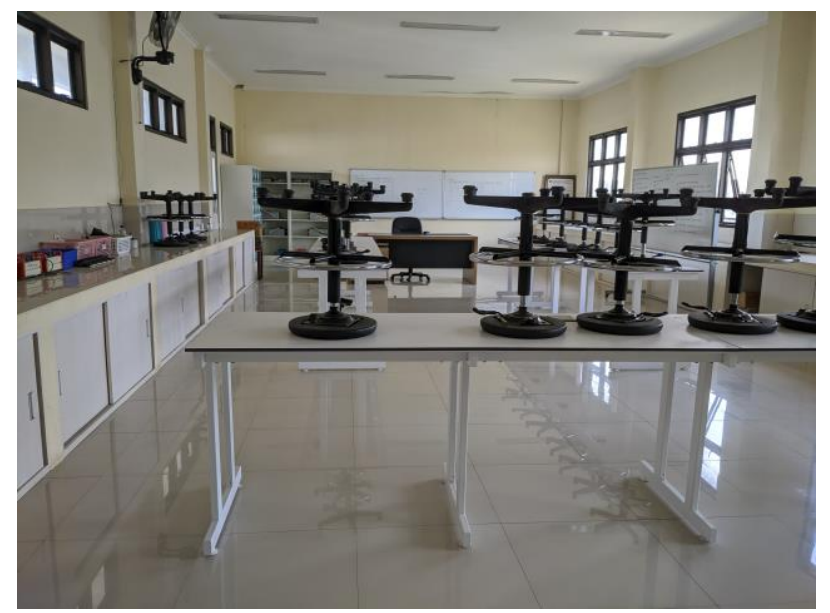

Gambar 1. Laboratorium Pendidikan Fisika FKIP Universitas Mataram.

Alat dan bahan yang digunakan antara lain; jangka sorong, micrometer sekrup, multimeter digital, multimeter analog, timbangan neraca ohaus lengan tiga dan catu daya.

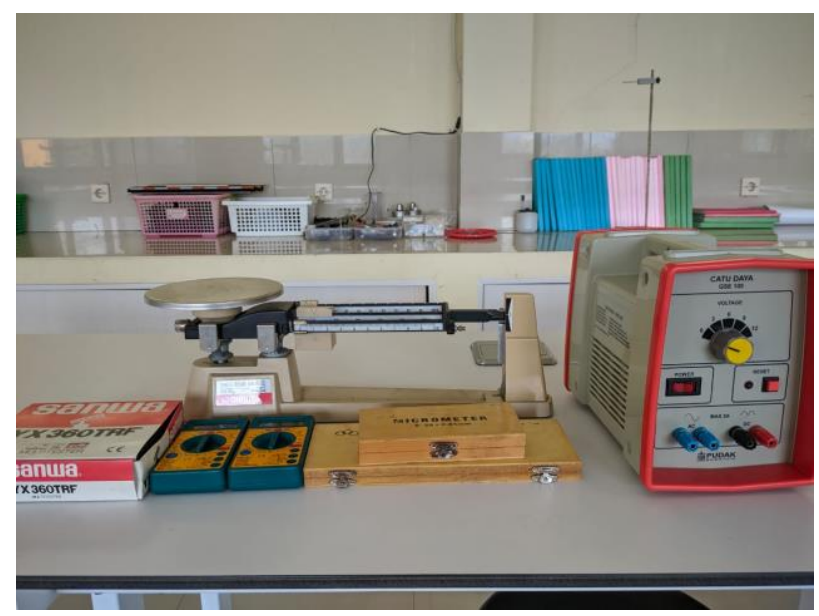

Gambar 2. Persiapan alat - alat Laboratorium

Bentuk kegiatan ini adalah edukasi cara penggunaan alat - alat laboratorium pendidikan fisika pada saat pembelajaran di sekolah dengan sasaran kegiatan adalah mahasiswa S1 Pendidikan MIPA FKIP Universitas Mataram selaku calon guru.

\section{Tahapan pelaksanaan}

1. Pengurusan izin 
Membuat surat permohonan izin penggunaan laboratorium Pendidikan fisika dari Program Studi Magister Pendidikan IPA Universitas Mataram kepada Dekan FKIP Universitas Mataram, kemudian Dekan memberikan disposisi kepada wakil Dekan I dan meneruskannya ke ketua program studi pendidikan Fisika sebagai penanggung jawab Laboratorium.

2. Persiapan alat dan bahan Mempersiapkan alat dan bahan yang akan digunakan seperti jangka sorong, micrometer sekrup, multimeter digital, multimeter analog, neraca ohaus lengan tiga dan catu daya serta membuat spanduk kegiatan kemudian mensetting tempat kegiatan.

3. Pelaksanaan kegiatan

Sebelum memberikan penjelasan kepada para peserta, terlebih dahulu diberikan pretest sebagai bentuk diagnosa sejauh mana para peserta memahami fungsi dan cara kerja alat alat laboratorium fisika.

Setelah melihat hasil pretest para peserta, mulai diberikan penjelasan cara kerja dan fungsi setiap alat laboratorium pendidikan Fisika. Kemudian pada sesi terakhir meminta para peserta mengerjakan soal posttest dengan soal yang sama.

4. Evaluasi

Evaluasi dilakukan sejalan dengan monitoring, sehingga jika ada kendala akan segera diselesaikan. Evaluasi dilakukan untuk menyatakan keberhasilan dari kegiatan yang dilakukan.

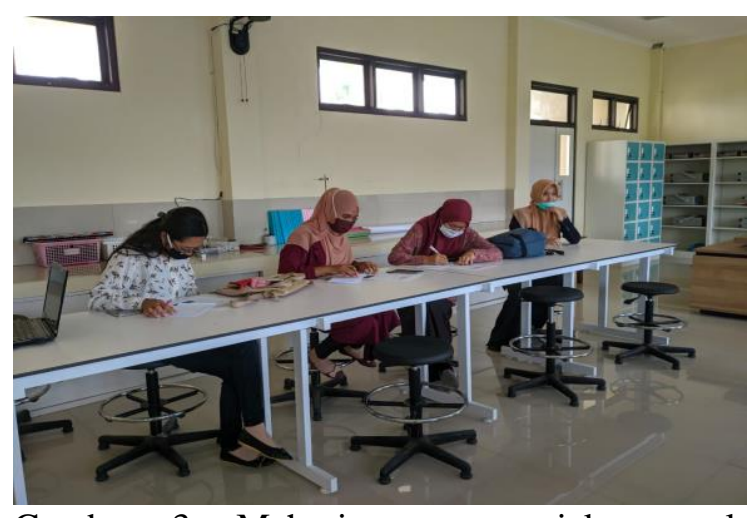

Gambar 3. Mahasiswa mengerjakan soal pretest

\section{Hasil dan Pembahasan}

\section{Permasalahan Mahasiswat/Sasaran Mitra}

Kelompok sasaran dalam program pengebadian ini adalah Mahasiswa S1 Jurusan Pendidikan MIPA FKIP Universitas Mataram. Hasil analisis situasi dapat dirumuskan beberapa permasalah diantaranya adalah: 1. Mahasiswa S1 Jurusan Pendidikan MIPA FKIP Universitas Mataram saat Pandemi belum pernah melakukan praktikum di Laboratorium secara langsung, sehingga pengetahuan dan keterampilan dalam mengoperasikan alat-alat Laboratorium masih kurang. 2. Mahasiswa S1 Jurusan Pendidikan MIPA FKIP Universitas Mataram belum memiliki keterampilan secara penuh dalam mengorepasikan alat-alat Laboratorim Fisika FKIP seperti, Catudaya. Multimeter Digital dan Analog, Mikrometer Sekrup, Jangka Sorong, dan Neraca Ohauss Lengan 3.

Sebagai calon pendidik, mahasiswa FKIP khususnya Jurusan Pendidikan Matematikan dan IPA seharusnya memiliki pengetahuan dan keterampilan dalam menggunakan alat-alat Laboratorium. Pengetahuan dan Keterampilan tersebut seharusnya didapatkan saat melakukan praktikum di Laboratorium, akan tetapi melihat situasi dan kondisi saat ini hal ini menjadi sulit untuk dilakukan. Untuk mengatasi hal tersebut peneliti melakukan pengabdikan dengan Tema Karateristik/spesifikasi alat Laboratorium Fisika dan cara penggunaanya pada Mahasiswa S1 Jurusan Pendidikan MIPA FKIP Universitas Mataram. Melalui kegiatan pelatihan ini diharapkan akan memperoleh pengetahuan dan pengalaman tentang alat laboratorium fisika.

\section{Jumlah Peserta}

Program pengabdian kepada mahasiswa S1 PMIPA FKIP Universitas Mataram tentang karakterisasi/spesifikasi alat - alat laboratorium Pendidikan Fisika baru pertama kali dilakukan. Para mahasiswa yang mengetahui acara tersebut sangat antusias untuk bisa mengikutinya khususnya program studi pendidikan MIPA sebagai calon guru. Namun karena kondisi covid-19 dan penerapan protokol kesehatan oleh pihak kampus maka pimpinan fakultas membatasi jumlah peserta yang mengikuti acara tersebut maksimum $20-25$ orang saja sehingga ketua program pendidikan fisika merekomendasikan 10 orang mahasiswanya untuk ikut dan sisanya berasal dari program studi 
biologi dan kimia masing - masing 5 orang sehingga berjumlah 20 orang mahasiswa.

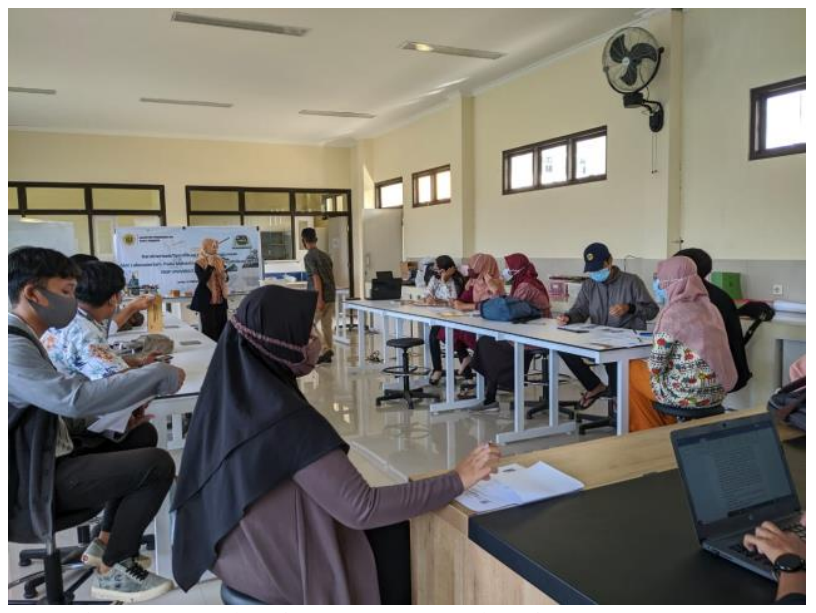

Gambar 4. Mahasiswa peserta kegiatan

\section{Karakteristik/Spesifikasi alat $\quad-\quad$ alat Laboratorium}

\section{Jangka sorong}

Jangka Sorong merupakan suatu alat ukur

yang mempunyai ketelitian tinggi hingga seperseratus $\mathrm{mm}$ dan digunakan untuk mengukur satuan Panjang, diameter dan kedalaman. Adapun bagian-bagian dari Janga Sorong yakni: 1) Skrup Pengunci (Locking Screw) berfungsi sebagai pengunci hasil pengukuran, sehingga hasil pengukuran tidak akan berubah ketika dipegang sehingga hasil tetap akurat, 2) Rahang Luar (Externnal Jaws) berfungsi untuk mengukur satuan Panjang, diameter luar sebuah silinder atau untuk mengukur ketebalan bentuk dimensi lainnya, 3) Rahang Dalam (Inner Jaws) berfungsi untuk pengukur bagian diameter dalam atau inside diameter, 4) Skala Utama, nilai yang menunjukkan hasil pengukuran yang satuannya dapat dalam mm, $\mathrm{cm}$ dan inchi, 5) Skala Nonius berfungsi sebagai skala pengukuran fraksi, untuk satuan dapat berupa $\mathrm{mm}, \mathrm{cm}$ dan inchi (Arief, 2015). Sedangkan besarnya biasanya $0,05,0,02$ dna sebagainya, 6) Kedalaman (Depth Probe), bagian ini berada di ujung dari Jangka Sorong yang berfungsi untuk mengukur bagian kedalaman suatu benda atau kedalaman sebuah lubang.

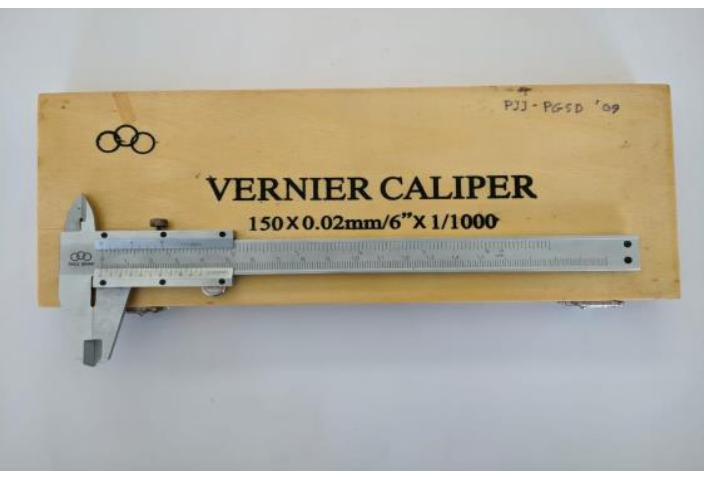

Gambar 5. Jangka sorong (Dok. Pribadi)

\section{Micrometer sekrup}

Mikrometer sekrup adalah alat pengukuran Panjang/ketebalan suatu benda (Murdoko, et al., 2017) yang terdiri dari sekrup terkalibrasi dan memiliki tingkat kepresisian $0.01 \mathrm{~mm}\left(10^{-5} \mathrm{~m}\right)$. Adapun bagian-bagian dari Mikrometer Sekrup yakni: 1) Poros Tetap (Anvil), bagian poros yang tidak bergerak. Objek yang ingin diukur ditempelkan di bagian ini dan bagian poros geser didekatkan untuk menjepit objek tersebut, 2) Poros Geser (Spindle), poros bergerak berbentuk komponen silindris yang digerakkan oleh thimble, 3) Pengunci (Lock Nut), bagian yang dapat digunakan untuk mengunci pergerakan poros geser, 4) Sleeve, bagian statis berbentuk lingkaran yang merupakan tempat ditulisnya skala pengukuran. Terdapat dua skala, yaitu skala utama dan skala nonius, 5) Thimble, bagian yang dapat digerakkan oleh tangan penggunanya, 6) Ratchet, bagian yang dapat membantu menggerakkan poros geser dengan pergerakan lebih perlahan dibanding menggerakkan thimble, dan 7) Rangka (Frame), komponen berbentuk $\mathrm{C}$ yang menyatukan poros tetap dan komponen-komponen lain mikrometer sekrup. Rangka mikrometer sekrup dibuat tebal agar kokoh dan mampu menjaga objek pengukuran tidak bergerak, bergesar, atau berubah bentuk.

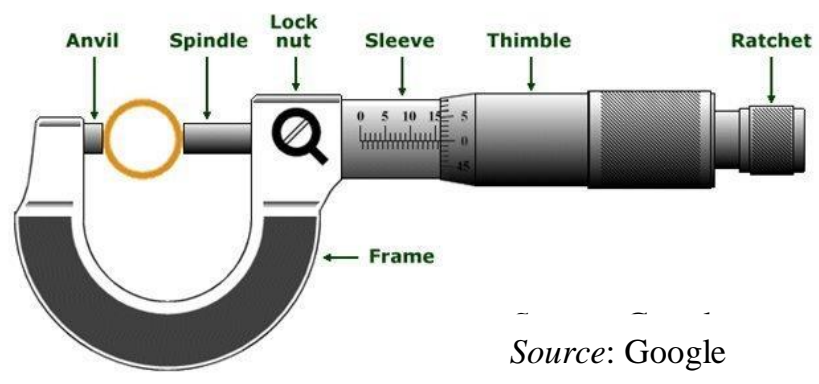

Gambar 6. Micrometer sekrup 


\section{Multimeter}

Multimeter merupakan alat ukur listrik yang banyak digunakan oleh teknisi di laboratorium dan bengkel elektronika, sedangkan fungsi utama dari multimeter ini ialah mengukur resistansi, kapasitansi, arus listrik, tegangan AC maupun DC, menguji baik atau tidaknya suatu komponen, mengetahui sambungan rangkaian dan sebagainya (Martias, 2017). Hal ini untuk mendeteksi apakah terjadi kerusakan atau gangguan sehingga menghindari kemungkinan timbulnya kebakaran atau konsleting listrik. Alat ukur rangkaian listrik ini terdiri dari 2 jenis yaitu kategori Analog dan Digital. Berikut penjelasan singkat mengenai jenis-jenis tersebut, 1) Analog, jenis alat ukur yang pertama yaitu analog dengan ciri-ciri berupa tampilan jarum jam yang dilengkapi dengan range-range angka hasil ukur. Dengan kata lain, jenis Analog lebih manual penghitungannya sehingga dibutuhkan ketelitian terutama saat menentukan tegangan atau Voltase yang cukup besar. Selain itu, akurasi hasil perhitungannya juga lebih rendah dibandingkan jenis Digital, 2) Digital, alat ukur jenis Digital lebih sering digunakan karena cara kerjanya jauh lebih mudah dan akurat. Hasil alat ukur dapat dengan mudah dibaca pada layar digital yang tertera. Istilah lain dari multitester jenis ini adalah DVOM (Digital Volt Ohm Meter) atau DMM (Digital Multi Meter). Pada tipe Digital, selain dapat mengukur Tegangan, Hambatan, serta Arus listrik, alat ukur ini juga mampu melakukan pengukuran pada Hfe transistor yang ada pada tipe-tipe tertentu saja.

\section{Multimeter digital}

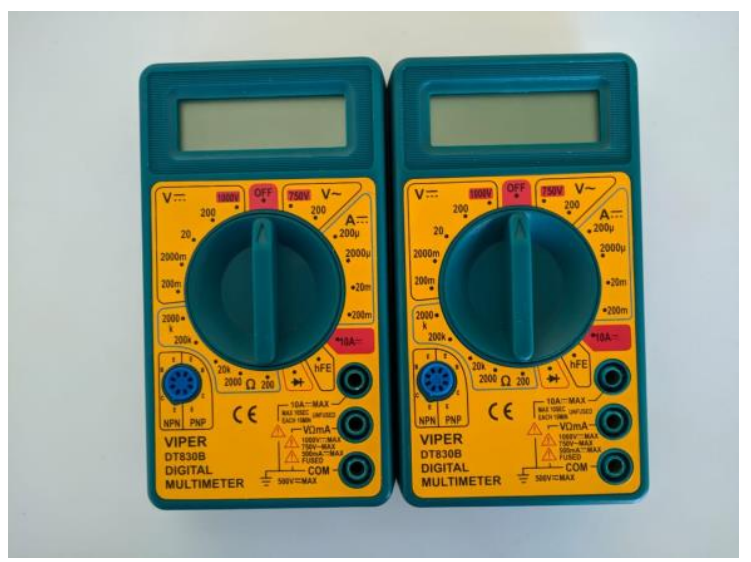

Gambar 7. Multimeter digital (dok. pribadi)

\section{Multimeter analog}

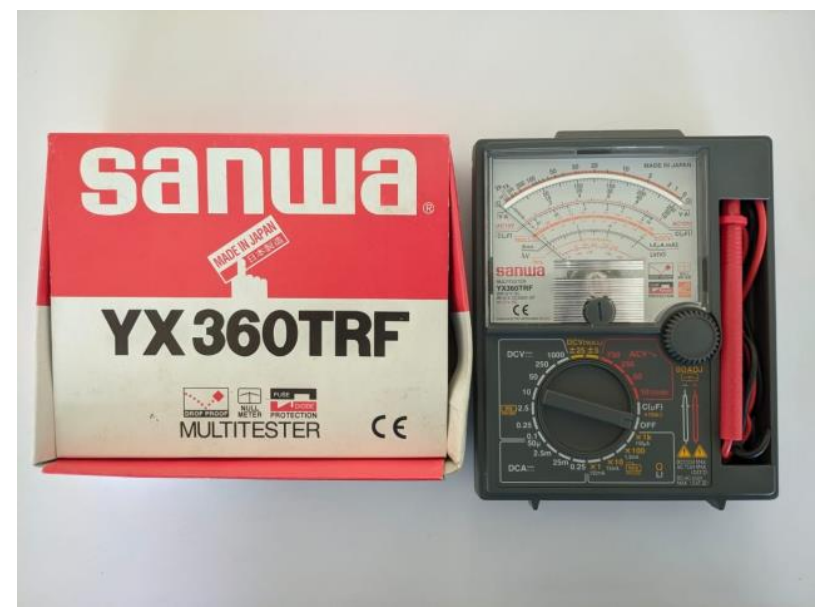

Gambar 8. Multimeter analog (dok. pribadi)

\section{Neraca ohaus lengan tiga}

Neraca ohaus merupakan salah satu alat ukur besaran fisika yaitu massa (Yandra, et al., 2016). Neraca ini sering digunakan dalam pengukuran laboratorium karena memiliki tingkat ketelitian yang tinggi yaitu mencapai 0,01 gram. Adapun bagian-bagian dari Neraca Ohaus yakni: 1) Tombol kalibrasi, merupakan sebuah sekrup atau knop yang digunakan untuk mengenolkan atau mengkalibrasi neraca ketika neraca akan digunakan, 2) Tempat beban, merupakan sebuah piringan logam yang digunakan untuk meletakkan benda yang akan diukur massanya, 3) Pemberat (anting), merupakan sebuah logam yang menggantung pada lengan yang berfungsi sebagai penunjuk hasil pengukuran. Pemberat dapat digeser-geser dan setiap lengan neraca memilikinya, 4) Lengan Neraca, merupakan plat logam yang terdiri dari skala dengan ukuran tertentu. Jumlah lengan pada neraca bisa 2, 3 atau 4 bergantung jenisnya. Masing-masing lengan menunjukkan skala dengan satuan yang berbeda, 5) Garis kesetimbangan (titik nol), digunakan untuk menentukan titik kesetimbangan pada proses penimbangan atau pengukuran massa benda. 


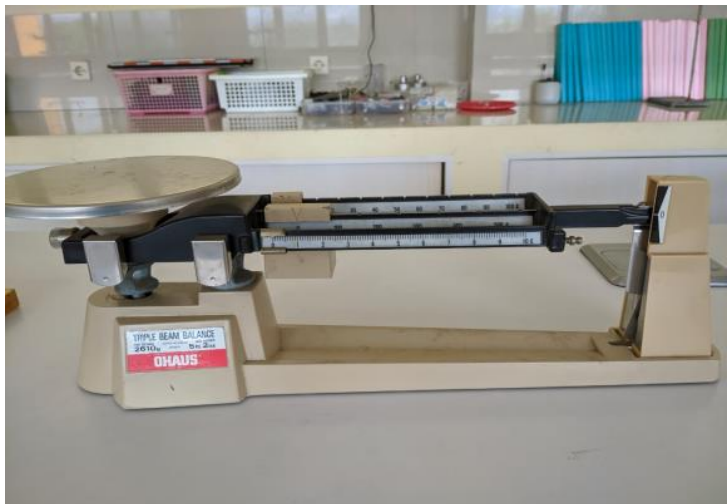

Gambar 9. Neraca ohaus lengan tiga (dok. pribadi)

\section{Catu daya}

Catu daya berfungsi untuk memberikan daya ke komponen-komponen yang digunakan dalam perancangan ini. Tegangan keluaran dari catu daya yang diperlukan adalah sebesar 5 Volt DC dan 12 Volt DC. Beberapa komponen yang terdapat pada catu daya DC adalah: 1) Trafo step down, sifat dari trafo step down adalah, tegangan keluarannya akan lebih kecil dibandingkan tegangan input. Tegangan yang dihasilkan oleh trafo tergantung dari lilitannya, 2) Dioda Penyearah/Rectifier, tegangan input catu daya adalah tegangan bolak-balik (Alternating Current/AC) sedangkan yang diperlukan adalah tegangan searah (Direct Current/DC), sehingga diperlukan dioda penyearah. Dioda ini akan mengubah arus bolak-balik menjadi arus searah, 3) Voltage Regulator berfungsi untuk mempertahankan nilai tegangan. Nilai tegangan yang dihasilkan apabila tidak menggunakan voltage regulator dapat naik atau turun sehingga dapat memperpendek usia pemakaian komponen. Dengan voltage regulator, nilai yang dihasilkan akan menjadi konstan dan tidak naik atau turun sehingga memperpanjang usia pemakaian komponen.

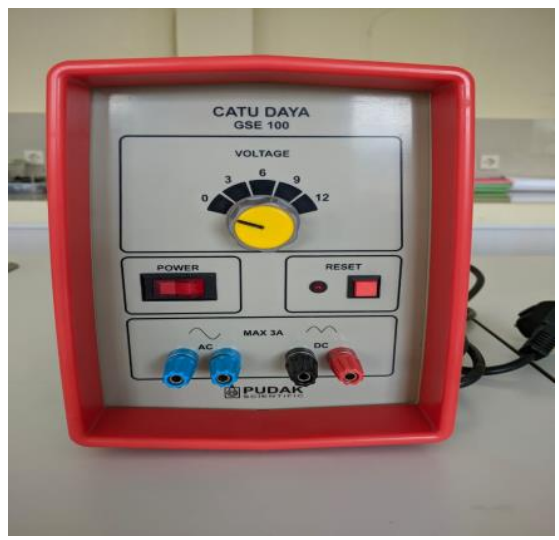

Gambar 10. Catu daya (dok. pribadi)

Kegiatan ini dimulai dengan mendiagnosa pemahaman awal para peserta dengan memberikan pretest kemudian dilanjutkan dengan menjelaskan karakteristik/spesifikasi dan cara penggunaan alat alat laboratorium secara berurutan mulai dari micrometer sekrup, jangka sorong, multimeter digital, multimeter analog, catu daya dan neraca ohaus lengan tiga masing - masing oleh tim peneliti.

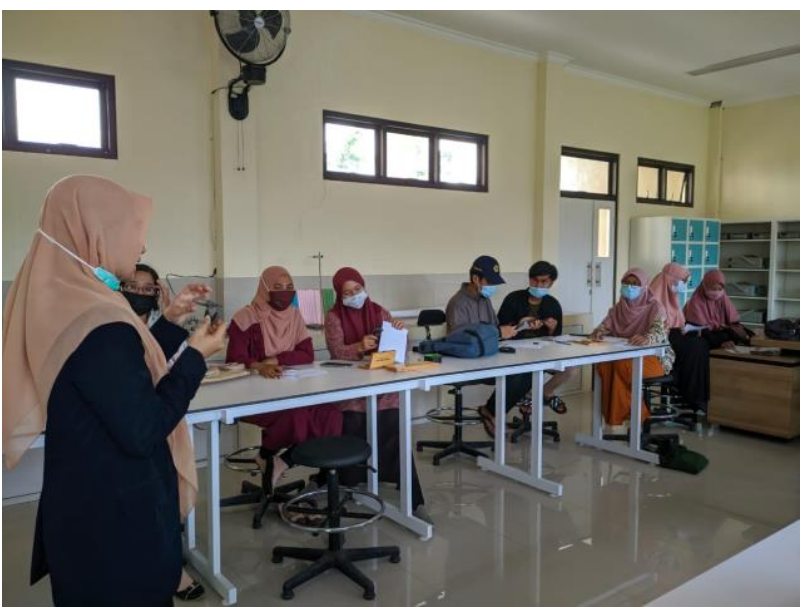

Gambar 4. Tim menjelaskan salah satu alat laboratorium

Kegiatan pengabdian ini sangat penting dilakukan untuk memberikan penjelasan secara benar dan tepat kepada mahasiswa PMIPA sebagai calon guru IPA di Sekolah. Setelah mengikuti kegiatan, mahasiswa merasa senang dan antusias untuk mempraktekkannya langsung sehingga terbangun konsep yang nyata dan tidak abstrak ketika menjelaskan alat - alat laboratorium. Hasil kegiatan ini menunjukkan bahwa para peserta kegiatan mengalami peningkatan pemahaman dan keterampilan cara menggunakan alat - alat laboratorium. Hal ini dibuktikan dari hasil posttest yang menunjukkan peningkatan nilai setelah diberikan penjelasan.

\section{Kesimpulan}

Karakteristik/spesifikasi alat - alat laboratorium pendidikan fisika dan cara penggunaanya sangat bermanfaat bagi mahasiswa S1 Pendidikan MIPA sebagai calon guru MIPA di Sekolah. Kegiatan ini memberikan wawasan tambahan yang ril tentang spesifikasi dan cara menggunakan alat laboratorium yang benar dan 
tepat. Pemahaman dan konsep mahasiswa terkait penggunaan alat - alat laboratorium meningkat secara signifikan.

\section{Ucapan terima kasih}

Terima kasih penulis sampaikan kepada Dr. Abdul Syukur, M.Si dan Dr. Jamaluddin, M.Pd selaku dosen pembimbing sehingga kami dapat menyelesaikan tugas pengabdian ini dengan baik dan lancer.

\section{Daftar pustaka}

Arief, D. S. (2015). Kalibrasi Jangka Sorong Nonius (Vernier Calliper) Berdasarkan Standar JIS B 7507 Di Laboratorium Pengukuran Teknik Mesin Universitas Riau (Doctoral dissertation, Riau University).

Ayuni, D., Marini, T., Fauziddin, M., \& Pahrul, Y. (2020). Kesiapan Guru TK Menghadapi Pembelajaran Daring Masa Pandemi Covid19. Jurnal Obsesi: Jurnal Pendidikan Anak Usia Dini. 5(1), 414-421.

Erni, S., Rian, V., Cut, R, M., Zubaidah, A, M, Z., Martius, \& Musa, T. 2020. Refleksi Proses Pembelajaran Guru MTs dimasa Pandemi Covid 19 di Pekanbaru: Dampak dan Solusi. Bedelau: Jurnal of Education and Learning. 1(1), 1-10.

Fuadi, H., Robbia, A. Z., Jamaluddin, J., \& Jufri, A. W. (2020). Analisis Faktor Penyebab Rendahnya Kemampuan Literasi Sains Peserta Didik. Jurnal Ilmiah Profesi Pendidikan, 5(2), 108-116.

Handayani, L. (2020). Peningkatan Motivasi Belajar IPA Melalui Model Pembelajaran Project Based Learning pada Masa Pandemi Covid-19 bagi Siswa SMP Negeri 4 Gunungsari. Jurnal Paedagogy. 7(3), 168174.

Martias, M. (2017). Penerapan Dan Penggunaan Alat Ukur Multimeter Pada Pengukuran Komponen Elektronika. Konferensi Nasional Ilmu Sosial dan Teknologi, 1(1).

Murdoko, E., Akhlis, I., \& Linuwih, S. (2017). Pengembangan Media Pembelajaran Alat Ukur Panjang Mikrometer Sekrup dan Jangka Sorong untuk Siswa SMA dengan Perangkat Lunak Construct 2. UPEJ Unnes Physics Education Journal, 6(3), 73-79.
Purwanto, A., Pramono, R., Asbari, M., Hyun, C. C., Wijayanti, L. M., \& Putri, R. S. (2020). Studi Eksploratif Dampak Pandemi COVID19 Terhadap Proses Pembelajaran Online di Sekolah Dasar. EduPsyCouns: Journal of Education, Psychology and Counseling. 2(1), $1-12$.

Sadikin, A., \& Afreni, H. (2020). Pembelajaran Daring di Tengah Wabah Covid-19. Jurnal Ilmiah Pendidikan Biologi. 6(2), 214-224.

Setiawan, A, R. (2020). Lembar Kegiatan Literasi Saintifik untuk Pembelajaran Jarak Jauh Topik Penyakit Coronavirus 2019 (COVID19). Edukatif: Jurnal Ilmu Pendidikan. 2(1), 28-37.

Sofyana, L., \& Abdul, R. (2019). Pembelajaran Daring Kombinasi Berbasis Whatsapp Pada Kelas Karyawan Prodi Teknik Informatika Universitas PGRI Madiun. Jurnal Nasional Pendidikan Teknik Informatika. 8(1), 81-86.

Yandra, E. F., Lapanporo, B. P., \& Jumarang, M. I. (2016). Rancang bangun timbangan digital berbasis sensor beban $5 \mathrm{Kg}$ menggunakan mikrokontroler Atmega328. POSITRON, 6(1). 